\title{
Detection of efflux pump activity among clinical isolates of Staphylococcus and Micrococcus species
}

\author{
Adebowale O Adeluola ${ }^{1,2 \star}$, Kolawole S Oyedeji ${ }^{3}$, Udoma E Mendie ${ }^{1}$, James R \\ Johnson $^{3}$ and John R Porter ${ }^{2}$ \\ ${ }^{1}$ Department of Pharmaceutics and Pharmaceutical Technology, Faculty of Pharmacy, College of Medicine, University of \\ Lagos, Lagos, Nigeria, ${ }^{2}$ Department of Biological Sciences, Misher College of Arts and Science, University of the Sciences, \\ Philadelphia, USA, ${ }^{3}$ Department of Medical Laboratory Science, College of Medicine, University of Lagos, Lagos, Nigeria
}

*For correspondence: Email: debodelu@gmail.com; aadeluola@unilag.edu.ng; Tel: +234-7056004859

Sent for review: 7 July 2017

Revised accepted: 11 October 2017

\begin{abstract}
Purpose: To detect efflux pump activity (EPA) and screening a suspected efflux pump inhibitor (EPI) [1(3-(trifluoromethyl)benzyl]-piperazine (TFMBP)], which could help in reducing multi-drug resistance (MDR).

Methods: Eighteen isolates, viz, $14 \mathrm{~S}$. aureus, $2 \mathrm{~S}$. lentus, $1 \mathrm{~S}$. xylosus and 1 Micrococcus species from various hospital infections of admitted patients were screened for antibiotics susceptibility to 11 classes of antibiotics including oxacillin and $\beta$-lactamase production. Efflux pump activity (EPA) was determined by minimum inhibitory concentration (MIC) technique in the presence and absence of TFMBP, the isolates were also screened for MDR genes.

Results: All the isolates were resistant to ampicillin $(10 \mu \mathrm{g})$ and penicillin $(10 \mu \mathrm{g})$, but sensitive to bacitracin $(10 \mu \mathrm{g})$. Majority of the isolates were MDR 12/18 (66.7\%), 10 (55.6\%) were inducible $\beta$ lactamase producers and 3 (16.7\%) were intrinsic $\beta$-lactamase producers. Seven (38.9\%) were resistant to oxacillin and also produced carbapenemase enzyme. Eight (66.7\%) of the 12 MDR isolates gave evidence of EPA with TFMBP. However, no MDR genes were detected.

Conclusion: Staphylococcus and Micrococcus species exhibit EPA in antibiotic resistance while a suitable EPI such as TFMBP when combined with specific antibiotics could help combat this menace.
\end{abstract}

Keywords: [1-(3-(Trifluoromethyl)benzyl]-piperazine, Efflux pump activity, Oxacillin resistant S. aureus, Multidrug resistant, Carbapenemase

Tropical Journal of Pharmaceutical Research is indexed by Science Citation Index (SciSearch), Scopus, International Pharmaceutical Abstract, Chemical Abstracts, Embase, Index Copernicus, EBSCO, African Index Medicus, JournalSeek, Journal Citation Reports/Science Edition, Directory of Open Access Journals (DOAJ), African Journal Online, Bioline International, Open-J-Gate and Pharmacy Abstracts

\section{INTRODUCTION}

Antibiotic drug development has dropped by about $75 \%$ since the 1980s [1,2] especially between 1962 and 2000. Despite the occurrence of methicillin-resistant Staphylococcus aureus (MRSA) reported in Nigerian secondary and tertiary hospitals [3-5], there is still a dearth of information on prevalence and types of multidrug-resistant (MDR) strains among Staphylococcus species, in Nigeria and sub- saharan Africa [6]. With more insight into the knowledge of the mechanisms of resistance in MDR bacteria, new initiatives in research into formulation of newer antibiotics or fortification of the existing ones for combating multi-drug resistant organisms will develop.

The typical phenotype of MRSA is multiple resistance to penicillin, oxacillin, cefuroxime, ciprofloxacin, erythromycin, clindamycin, sulphamethoxazole, and gentamicin, amongst other classes of antibiotics [7]. MDR exhibited by 
bacterial organisms to chemically-unrelated antibacterial agents are caused by overexpression of MDR efflux pumps (which are transport proteins). This process leads to the extrusion of toxic substances including clinicallyrelevant antibiotics (which help in combating the pathogenic organisms) into the external environment. These pump proteins are found in both Gram-positive and Gram-negative bacteria, as well as in eukaryotic organisms [8].

Bohnert and Kern [8], studied a number of arylpiperazines for their ability to reverse multidrug resistance in E. coli over-expressing RND (Resistance Nodulation-Division) efflux pumps. Among them, 1-[3-(trifluoromethyl) benzyl]piperazine (TFMBP) $(200 \mu \mathrm{g} / \mathrm{mL})$ was found to lower the effective MIC of levofloxacin four-fold.

In recent times, antimicrobial resistance phenotypes are predicted by identifying and characterising the known genes that encode the specific resistance mechanisms. The methods of Polymerase Chain Reaction (PCR) and DNA sequencing are known to offer the promise of increased sensitivity, specificity and speed in the detection of such specific known resistance genes $[9,10]$. Therefore, this study was conducted to identify and determine the genes responsible for efflux pump activity in different isolates of Staphylococcus and Micrococcus species using PCR.

\section{EXPERIMENTAL}

\section{Microbial isolates}

Eighteen clinical isolates comprising of $14 \mathrm{~S}$. aureus, $2 S$. lentus, 1 S. xylosus and 1 Micrococcus spp. from infections of urinary tract, upper respiratory tract, ear and eye swab, and blood culture all were identified by the analytical profile index (API) and the analytical profile index web (APIWeb) were used. S. aureus (ATCC 25923) was used as the standard strain in the study.

\section{Antibiotics susceptibility test}

Antibiotics susceptibility testing was carried out as described by Bauer et al [11] on the isolates. Ampicillin-10 $\mu \mathrm{g}$ (Amp-10), penicillin-G $10 \mu \mathrm{g}$ (P10), ceftriaxone-30 $\mu \mathrm{g}$ (CRO-30), ciprofloxacin-5 $\mu \mathrm{g} \quad$ (CIP-5), tetracycline-30 $\mu \mathrm{g}$ (Te-30), cotrimoxazole-1.25 $\mathrm{\mu g}+23.75 \mu \mathrm{g}$ (SXT$1.25 / 23.75)$, neomycin-30 $\mu \mathrm{g}(\mathrm{N}-30)$, erythromycin-15 $\mu \mathrm{g}(\mathrm{E}-15)$, polymyxin-B-300 i.u. (PB300), lincomycin-2 $\mu \mathrm{g}(\mathrm{L}-2)$, chloramphenicol-30 $\mu \mathrm{g} \quad$ (C-30) and bacitracin-10 $\mu \mathrm{g}$ (B-10) representing 11 classes of antibiotics were used.
For further testing, all strains found to be resistant to four or more classes of antibiotics were classified as MDR.

\section{$\beta$ - Lactamase assay}

All isolates showing resistance to the $\beta$-lactam antibiotics were further tested for the production of $\beta$-lactamase enzyme using nitrocefin (NF), a "colour shift substrate" as described by Livermore and Brown [12]. The standard strains, E. coli A (non $\beta$-lactamase producing) and E. coli $B$ ( $\beta$-lactamase producing) used were collected from McNeil Science and Technology culture collection Centre (Usciences, Philadelphia). The tests were performed as follows; In the blank assay, $0.25 \mathrm{~mL}$ sterile Mueller Hinton Broth (MHB) and $0.25 \mathrm{~mL}$ of NF assay solution was added to the $0.5 \mathrm{~mL}$ of $0.01 \mathrm{M} \mathrm{Na}$-HEPES, while in the reaction assay the $0.25 \mathrm{~mL}$ sterile MHB was replaced with $0.25 \mathrm{~mL}$ of broth culture. A color change from yellow to red in the reaction solution within 10 minutes compared with the blank was indicative of the presence of intrinsic $\beta$-lactamase producer [12]. While, strains showing the color change after $10 \mathrm{~min}$ were considered as inducible $\beta$-lactamase producers [12].

\section{Detection of antibiotic resistance with the modified double disc synergy test (MDDST)}

A twelve-disk procedure was carried out on the MDR isolates with the antibiotics CRO-30, ceftazidime-30 $\mu \mathrm{g} / \mathrm{clavulanate-10 \mu \textrm {g }}$ (CAZ/CLA-

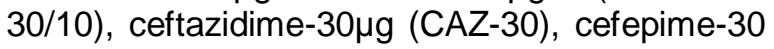
$\mu \mathrm{g}$ (FEP-30), cefoxitin-30 $\mu \mathrm{g}$ (FOX-30), aztreonam-30 $\mu \mathrm{g}$ (ATM-30), eterpenem-10 $\mu \mathrm{g}$ (ERT-10), imipenem-10 $\mu \mathrm{g}$ (IMP-10), oxacillin-1 $\mu \mathrm{g}(\mathrm{OX}-1)$, vancomycin-30 $\mu \mathrm{g}$ (Va-30), ampicillin$20 \mu \mathrm{g} /$ clavulanic acid-10 $\mu \mathrm{g}$ (AmC-30), and ampicillin-10 $\mu \mathrm{g} /$ sulbactam-10 $\mu \mathrm{g}$ (SAM-20). Zones of inhibition obtained were compared with the Zone Diameter Interpretative Standards from the disc manufacturers and CLSI. These were used to classify each organism as resistant, intermediate or susceptible to the antibiotics [13].

\section{Efflux pump activity (EPA) test}

MDR isolates were further tested for EPA. The MICs of the test drugs were determined in the presence and absence of TFMBP as EPI. A reduction in MIC in the presence of the EPI indicates resistance due to EPA in the MDR isolates [8].

Eleven of the isolates tested (of which seven were found to be Oxacillin resistant $S$. aureus ORSA from the MDDST), were picked for this 
test. The four drugs used in this test were amoxicillin, cefuroxime, ciprofloxacin and tetracycline. These represent four classes of antibiotics to which the MDR organisms were commonly resistant. A total of 37 tests were performed using amoxicillin - 11 isolates, cefuroxime - 7 isolates, ciprofloxacin - 8 isolates, and tetracycline -11 isolates.

\section{Method 1: Broth macro-dilution}

The broth macro-dilution (tube method) was used to determine initial range of the MICs of these drugs against the isolates. Four milliliters of sterile Mueller Hinton broth (MHB) containing serially diluted antibiotic in each of 11 test tubes, beginning with $1000 \mu \mathrm{g} / \mathrm{mL}$ of test antibiotic in tube no. 1 to $0.9765 \mu \mathrm{g} / \mathrm{mL}$ in the $11^{\text {th }}$ tube were set up for the test. Tubes 12 and 13 containing 4 $\mathrm{mL}$ of MHB were also set up as growth and sterile controls. Overnight fresh broth (18 h) culture of each isolate was diluted to give a $1: 10^{3}$ dilution in normal saline (equivalent to 0.5 McFarland standard), and $0.1 \mathrm{~mL}$ of this was introduced into each tube from the second tube to the $12^{\text {th }}$ tube. The twelfth tube, which contained no antibiotic was the growth control, while the $13^{\text {th }}$ tube with only $4 \mathrm{~mL}$ of sterile MHB served as the sterility control. All of the tubes from the $2^{\text {nd }}$ to the $13^{\text {th }}$ were incubated at $35^{\circ} \mathrm{C}$ for $18 \mathrm{~h}$.

The MIC was thereafter determined by measuring optical density (OD) at $550 \mathrm{~nm}$ in a Spectronic Thermo 20 Genesys spectrophotometer against an un-inoculated MHB as the reference blank. The tube with the lowest concentration that completely inhibited growth was taken as the MIC. A similar procedure was carried out for each of the antibiotics tested.

\section{Method 2: Broth micro-dilution}

MDR isolates were subjected to another round of MIC tests employing the micro-dilution assay method in micro-titer plates. The 96-well microtiter plates were used to perform the MIC tests at different concentrations of the antibiotics against the bacterial strains based on the result of the initial macro-dilution assay.

The desired range of concentrations of each antibiotic for the MIC tests was initially obtained through serial double-dilution of each antibiotic in a twelve-channel basin. Sterile phosphate buffer, $\mathrm{pH} 6.0$ was used as diluent for amoxicillin and cefuroxime while sterile water was used for tetracycline and ciprofloxacin. In the case of each antibiotic, starting with a stock concentration of $2000 \mu \mathrm{g} / \mathrm{mL}$ in channel 1 of a twelve-channel basin, the serial double dilution was carried out up to a final concentration of $0.97663 \mu \mathrm{g} / \mathrm{mL}$ in the $12^{\text {th }}$ channel.

One micro-titer plate was used to test two different drugs (in duplicates) at a time and at ten different concentration levels from well $A 1$ to well $\mathrm{H} 10$. The 11th column of wells $(\mathrm{A} 11-\mathrm{H} 11)$ was for the growth control of the strain, while the $12^{\text {th }}$ column of wells (A12-H12) was for a sterility control of the process (Table 1 ).

\section{Preparation of microdilutions in microtiter plate}

EPA test for each drug was done in duplicate in the micro-titer plate. For example, rows $A$ and $B$ were for amoxicillin with TFMBP, $C$ and $D$ for amoxicillin without TFMBP, $\mathrm{E}$ and $\mathrm{F}$ for cefuroxime with TFMBP, and $G$ and $H$ for cefuroxime without TFMBP. This was done for all the drugs used.

Table 1 shows materials required per column in each row of wells for MIC determination in the presence of the EPI.

For determination of MICs in the absence of the $\mathrm{EPI}, 34 \mu \mathrm{L}$ of make-up volume of sterile phosphate buffer or sterile water (for water soluble antibiotics) was added instead.

Thirty-seven EPA tests were carried out as specified in Table 1. The plates were then incubated at $35{ }^{\circ} \mathrm{C}$ for $18 \mathrm{~h}$. after which the optical density (OD) of each well in the plates, were read at $650 \mathrm{~nm}$ in a micro-titer plate reader, Spectramax plus (384).

\section{Molecular analysis}

The DNA of the isolates were extracted and the genotyping was done by Randomly-Amplified Polymorphic DNA (RAPD)-PCR and the PCR products were analysed using the agarose gel electrophoresis [14]. DNA quantification and check for purity was also done as described in literature [14]. For each chromosomal DNA sample, a PCR mix of $25 \mu \mathrm{L}$ containing magnesium chloride (6\%; $1.5 \mu \mathrm{L})$, forward and reverse primers $(0.8 \% ; 0.2 \mu \mathrm{L}$ each) for each of the genes to be screened was used. The PCR was conducted by an initial denaturation at $95{ }^{\circ} \mathrm{C}$ for $5 \mathrm{~min}$. followed by 30 cycles of denaturation at $95^{\circ} \mathrm{C}$ for $30 \mathrm{sec}$.

The annealing step was done for $60 \mathrm{sec}$. at various temperatures to suit each primer pair followed by elongation at $72{ }^{\circ} \mathrm{C}$ for $60 \mathrm{sec}$ according to the manufacturer's specification. 
Table 1: Composition of microtiter wells for MIC determination in the presence of $200 \mu \mathrm{g} / \mathrm{mL}$ of TFMBP

\begin{tabular}{|c|c|c|c|c|c|c|c|c|c|c|c|c|}
\hline Variable & 1 & 2 & 3 & 4 & 5 & 6 & 7 & 8 & 9 & 10 & 11 & 12 \\
\hline MHB $(\mu \mathrm{l})$ & 111 & 111 & 111 & 111 & 111 & 111 & 111 & 111 & 111 & 111 & 111 & 111 \\
\hline Drug $(\mu \mathrm{l})$ & 50 & 50 & 50 & 50 & 50 & 50 & 50 & 50 & 50 & 50 & 0 & 0 \\
\hline $\begin{array}{l}\text { TFMBP stock }(\mu \mathrm{l}) \\
(1179 \mu \mathrm{g} / \mathrm{ml})\end{array}$ & 34 & 34 & 34 & 34 & 34 & 34 & 34 & 34 & 34 & 34 & 0 & 0 \\
\hline $\begin{array}{l}\text { Make up } \\
\text { water/buffer }(\mu \mathrm{l})\end{array}$ & 0 & 0 & 0 & 0 & 0 & 0 & 0 & 0 & 0 & 0 & 84 & 89 \\
\hline Broth culture $(\mu \mathrm{l})$ & 5 & 5 & 5 & 5 & 5 & 5 & 5 & 5 & 5 & 5 & 5 & 0 \\
\hline $\begin{array}{l}\text { Total Volume/well } \\
(\mu \mathrm{l})\end{array}$ & 200 & 200 & 200 & 200 & 200 & 200 & 200 & 200 & 200 & 200 & 200 & 200 \\
\hline $\begin{array}{l}\text { Final drug } \\
\text { concentrations } \\
(\mu \mathrm{g} / \mathrm{ml})\end{array}$ & 125 & 62.5 & 31.25 & 15.63 & 7.83 & 3.91 & 1.95 & 0.97 & 0.49 & 0.24 & 0 & 0 \\
\hline $\begin{array}{l}\text { Drug Stock } \\
\text { solution } \mu \mathrm{g} / \mathrm{ml}\end{array}$ & 500 & 250 & 125 & 62.5 & 31.25 & 15.62 & 7.813 & 3.906 & 1.953 & 0.976 & $\begin{array}{l}\text { Growth } \\
\text { control }\end{array}$ & $\begin{array}{l}\text { Sterility } \\
\text { control }\end{array}$ \\
\hline
\end{tabular}

Table 2: Nucleotide sequence of primers used

\begin{tabular}{lrc}
\hline Primer & \multicolumn{1}{c}{ Nucleotide sequence } & Phenotype \\
\hline Nor A-F (EFFLUX) & 5'-ACT ATA CAC AGC TGA CAA GG- 3' & Efflux pump activity \\
Nor A-R (EFFLUX) & 5'-GAA TTA GGT ATG TGG ATT GC-3' & Efflux pump activity \\
Nor A2-F (RES) & 5'-TCG CCA TTC GGT GGT ACG TTA GC- 3' & Efflux pump activity \\
Nor A2-R (RES) & 5'-AAC CCA CCT GCA AAT CCC TGT CT- 3' & Efflux pump activity \\
mecA-F & AAA ATC GAT GGT AAA GGT TGG C & Oxacillin resistant $S$. aureus \\
mecA-R & AGT TCT GCA GTA CCG GAT TTG C & Oxacillin resistant $S$. aureus \\
Luk-PV-1 & ATC ATT AGG TAA AAT GTC TGG ACA TGA TCC A & Oxacillin resistant $S$. aureus \\
Luk-PV-2 & GCA TCA AGT GTA TTG GAT AGC AAA AGC & Oxacillin resistant $S$. aureus \\
\hline
\end{tabular}

The final elongation step was done at $72{ }^{\circ} \mathrm{C}$ for $10 \mathrm{~min}$. The primers used for the PCR were as listed in Table 2 for Nor-A (efflux), Nor-A (resistance), mecA and luk- $P v /$ resistant genes.

\section{Data analysis}

Data entry, coding, cleaning and analysis were done using Excel 2013 software. Descriptive statistics such as mean, maximum and minimum were summarized.

\section{RESULTS}

\section{Antibiotics susceptibility}

All of the clinical isolates tested in this study were resistant to Amp-10 and P-10 but sensitive to $B$ 10. Most of the isolates were sensitive to C-30 (88.8 \%) and SXT-1.25/23.75 (66.7\%) (Table 3). Among the 18 clinical isolates tested, 12 isolates $(66.7 \%)$ were found to be MDR. Of these, eight isolates were $S$. aureus $(66.7 \%)$, two $S$. lentus (16.7\%), one $S$. xylosus $(8.3 \%)$, and one Micrococcus sp. (8.3 \%). Ten (55.6\%) of the 18 isolates were inducible $\beta$-lactamase producers, three $(16.7 \%)$ were intrinsic $\beta$-lactamase producers, and five $(27.7 \%)$ had no $\beta$-lactamase activity (Figure 1).

\section{Oxacillinase and carbapenemase from MDDST}

Five $S$. aureus isolates $(27.8 \%)$ and one $S$. lentus $(5.6 \%)$ were ORSA and carbapenemase producers while the only Micrococcus sp. (5.6\%) tested was MDR, ORSA, and a carbapenemase producer (Figure 1).

\section{EPA with TFMBP}

Of the $12 \mathrm{MDR}$ isolates tested, nine $(75.0 \%)$ gave evidence of EPA against at least one of the tested antibiotics. The only Micrococcus sp. tested showed EPA against three drugs and a 16-fold reduction in MIC for only ciprofloxacin when TFMBP was used (Table 4).

\section{MDR and EPA genes}

No MDR and EPA genes were detected in the screened isolates in this study (Figure 2). There were no amplifications for any gene detection from all the primers used such as NorA (Resistance), NorA (efflux) and MecA used in this study. 
Table 3: Antibacterial susceptibility of the clinical isolates

\begin{tabular}{|c|c|c|c|c|c|c|c|}
\hline \multirow[t]{2}{*}{ Antimicrobial agent } & \multirow{2}{*}{$\begin{array}{c}\text { No of } \\
\text { isolates } \\
\text { tested }\end{array}$} & \multicolumn{2}{|c|}{ Sensitive } & \multicolumn{2}{|c|}{ Intermediate } & \multicolumn{2}{|c|}{ Resistant } \\
\hline & & $N$ & $\%$ & $N$ & $\%$ & $N$ & $\%$ \\
\hline Ampicillin 30 ug & 18 & 0 & 0 & 0 & 0 & 18 & 100 \\
\hline Penicillin G $10 \mu \mathrm{g}$ & 18 & 0 & 0 & 0 & 0 & 18 & 100 \\
\hline Ceftriaxone $30 \mu \mathrm{g}$ & 18 & 11 & 61.1 & 1 & 5.6 & 6 & 33.3 \\
\hline Ciprofloxacin $5 \mu \mathrm{g}$ & 18 & 9 & 50 & 3 & 16.7 & 6 & 33.3 \\
\hline Tetracycline $30 \mu \mathrm{g}$ & 18 & 2 & 11.1 & 1 & 5.6 & 15 & 83.3 \\
\hline SXT-1.25/23.75 & 18 & 12 & 66.7 & 0 & 0 & 6 & 33.3 \\
\hline Neomycin $30 \mu \mathrm{g}$ & 18 & 10 & 55.6 & 0 & 0 & 8 & 44.4 \\
\hline Erythromycin $15 \mu \mathrm{g}$ & 18 & 10 & 55.6 & 3 & 16.7 & 5 & 27.7 \\
\hline Chloramphenicol $30 \mu \mathrm{g}$ & 18 & 16 & 88.8 & 1 & 5.6 & 1 & 5.6 \\
\hline Bacitracin $10 \mu \mathrm{g}$ & 18 & 18 & 100 & 0 & 0 & 0 & 0 \\
\hline Lincomycin $2 \mu \mathrm{g}$ & 18 & 11 & 61.1 & 0 & 0 & 7 & 38.9 \\
\hline Mean \pm SEM & & $\begin{array}{c}9.9 \pm \\
1.734935\end{array}$ & & $\begin{array}{c}0.9 \pm \\
0.378594\end{array}$ & & $7.2 \pm 1$ & \\
\hline
\end{tabular}

SXT: cotrimoxazole

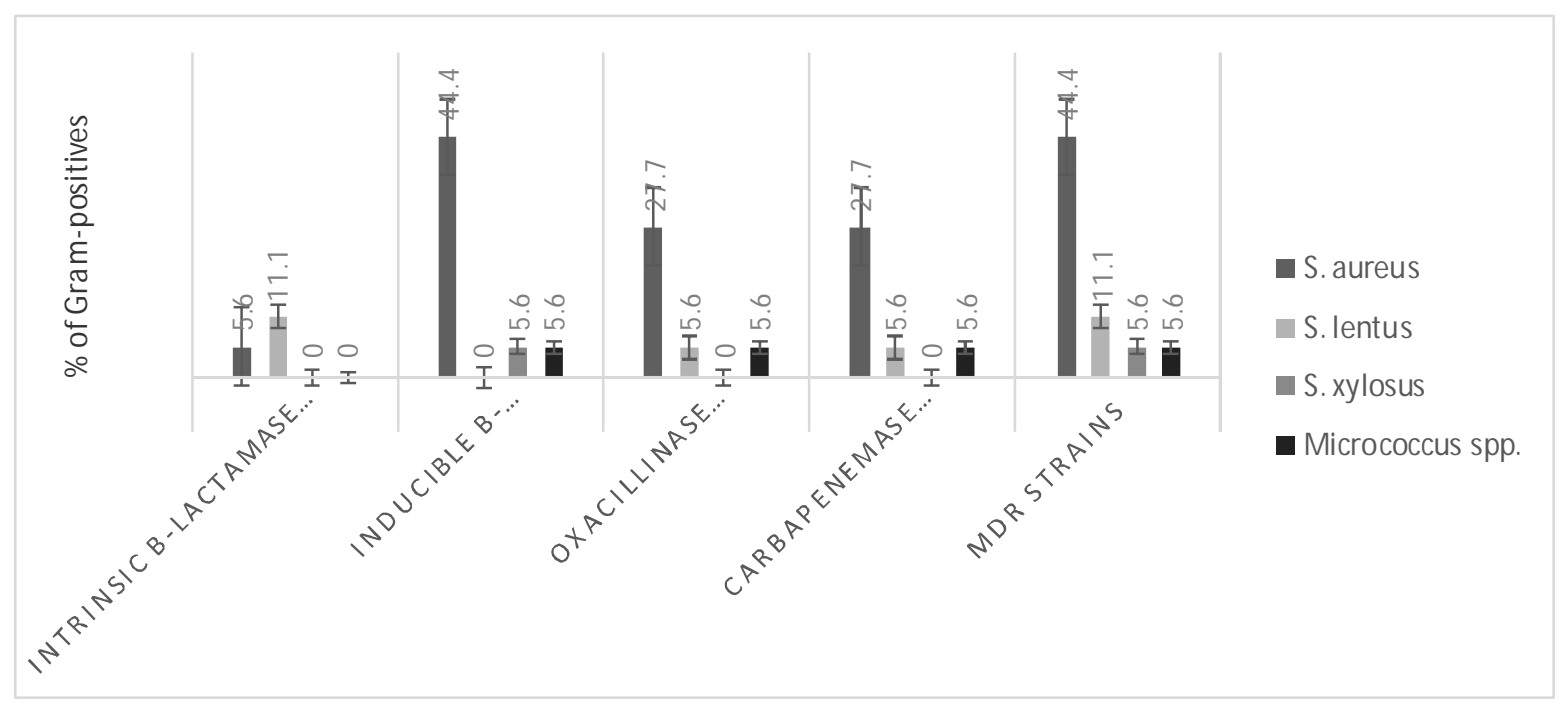

Figure 1: Types of resistance traits exhibited by the clinical isolates tested

Table 4: Summary of EPA findings on MDR isolates with TFMBP $(200 \mu \mathrm{g} / \mathrm{ml})$ as EPI

\begin{tabular}{|c|c|c|c|c|c|c|}
\hline \multirow[t]{2}{*}{ Isolate } & \multirow[t]{2}{*}{ Source } & \multicolumn{4}{|c|}{$\begin{array}{c}\text { Efflux pump activity with TFMBP } \\
\text { (- fold reduction in MIC) }\end{array}$} & \multirow{2}{*}{$\begin{array}{l}\text { Number of } \\
\text { antibiotics with } \\
\text { reduced MIC }\end{array}$} \\
\hline & & Tetracycline & Ciprofloxacin & Amoxicillin & Cefuroxime & \\
\hline S. aureus & Semen & - & 2 & - & - & 1 \\
\hline S. aureus & Ear swab & 2 & 2 & - & - & 2 \\
\hline S. aureus & Blood & - & - & - & - & 0 \\
\hline S. aureus & Eye swab & - & - & - & - & 0 \\
\hline S. aureus & Eye swab & - & - & - & 4 & 1 \\
\hline S. aureus & Sputum & - & - & - & 2 & 1 \\
\hline S. aureus & Blood & - & - & - & - & 0 \\
\hline S. aureus & Catheter & - & - & - & - & 0 \\
\hline S. lentus & Semen & - & 2 & - & - & 1 \\
\hline S. lentus & Ear swab & 4 & 4 & - & - & 2 \\
\hline S. xylosus & Wound & 4 & 4 & - & - & 2 \\
\hline Micrococcus sp. & Blood & 4 & 16 & - & 2 & 3 \\
\hline Total $^{*}$ & & 4 & 6 & 0 & 3 & \\
\hline
\end{tabular}

TFMBP: Trifluoro-methyl, benzyl piperazine, EPA: Efflux pump activity, EPI: Efflux pump inhibitor; - Less than 2 fold reduction in MIC; * total number of bacterial strains with reduced EPA 


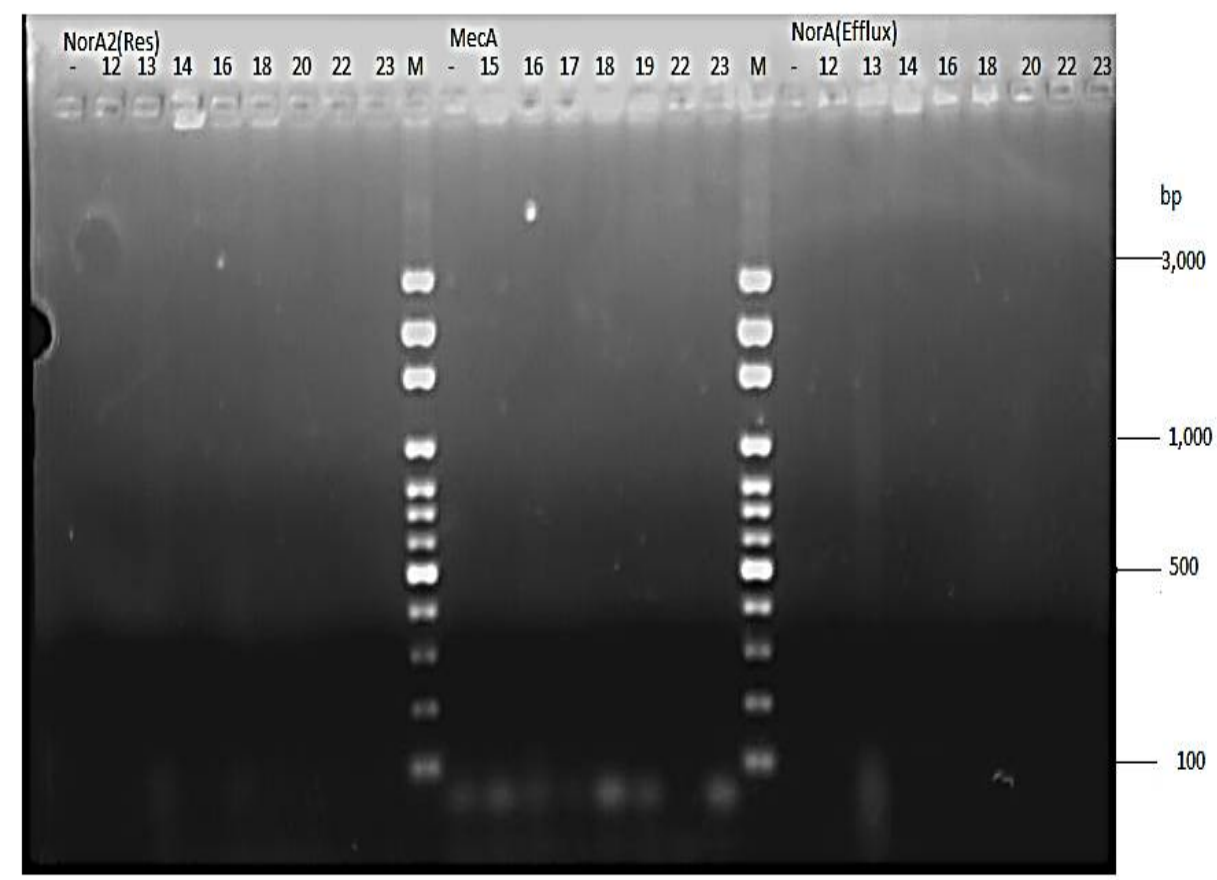

Figure 2: Agarose gel electrophoresis of $\operatorname{NorA}($ Res), NorA(efflux) and MecA amplicons. Key: $M=$ Molecular size marker (100 bp DNA ladder). The samples were on the lanes labelled with Arabic numerals

\section{DISCUSSION}

All the ceftriaxone-resistant strains studied were MDR. Some of these were ORSA but were susceptible to sulphamethoxazole/trimethoprim. This proves that sulphamethoxazole/trimethoprim has a good spectrum of activity against $S$. aureus, including several ORSA strains [15].

The frequency of MRSA among the clinical isolates tested corroborates the findings of Zinn et al in Southern European countries, some parts of the United States, Asia and South Africa [16]. Though this frequency is lower than the one recorded by Hong et al [17], from tertiary hospitals in Korea, it is a trend that needs to be surveyed regularly and checked. In this study, not all of the MDR isolates were sensitive to lincomycin, suggesting that lincosamides have a moderate spectrum of activity for $S$. aureus, including some MRSA while all of the Staphylococcus spp. were found to be resistant to both ampicillin and penicillin suggesting all of the species to be penicillinase-producing.

However, studies conducted in hospitals in Northern Europe, United States, New Zealand, and Australia recorded a much lower frequency [16] than was observed in this study. This may suggest effective control of antibiotics use compared to our environment, where there is less control.

When compared with this study, Shittu et al [6] recorded a lower percentage $(16 \%)$ of ORSA from clinical and non-clinical sources from different parts of Nigeria. They also recorded lower resistance to tetracycline compared with the results from this study. Our results may be evidence of widespread exposure to antibiotics in the hospital environment, suggestive of hospitalacquired resistance traits compared to nonclinical environments.

All of the ORSA strains were confirmed as MDR $S$. aureus, which were resistant to at least four classes of antibiotics similar to other findings [18]. Some of the clinical isolates that turned out to be MDR and ORSA strains may not pose any clinical risk on their own. The fact that they are isolated from the vicinity of infections and around patients pose the danger of dissemination of dangerous genetic traits to less harmful pathogenic strains around them [19]. This can lead to complications in therapy of otherwise easily-treatable disease conditions. Therefore, the occurrence of such MDR and ORSA traits in the supposed non-pathogenic organisms cannot be overlooked.

As observed in this study, the EPI (TFMBP), with an intrinsic MIC $>400 \mu \mathrm{g} / \mathrm{mL}$, is unlikely to have any appreciable antibacterial activity of its own [20]. It was found to appreciably lower MICs of up to two or three drugs in some of the MDR isolates tested. This is consistent with other reports [21,22] that a single pump is able to confer resistance to multiple compounds. The efflux pump inhibition in organisms from the various clinical sources tested further 
underscores the suggestion that the use of such inhibitors, in association with substrate antibiotics, may be useful for increasing both the activity and the range of species for which such drugs may be effective [23]. Therefore, it is important to do more research on EPIs in combating MDR strains. This may help in reducing the threat of EPA in resistance mechanisms among these organisms. It is pertinent to mention that the findings in this study are in support of the prediction that the use of bacterial resistance modifiers, such as EPIs, could facilitate the re-introduction of therapeutically-ineffective antibiotics [22], such as tetracycline, amoxicillin, and others, back into clinical use and might even suppress the emergence of MDR strains, if effectively managed.

In this study, all the $S$. aureus isolates with phenotypic resistance to oxacillin were tested for the carriage of the mecA, Luk-PV, Nor-A (efflux) and Nor-A (resistance) genes. None of these genes were detected in the tested isolates. This is similar to the result obtained in other works [24] in which mecA gene was not found in the tested MRSAs. Other genes such as the Luk-PV for the PVL gene in the ORSAs were not present in the isolates tested, this is corroborated in the result obtained from other workers in which PVL in MRSA was not isolated but PVL in MSSA was observed [25].

From this study, it may be suggested that MDR Staphylococcus and Micrococcus obtained from clinical isolates should be tested to determine the type of resistance involved. This in turn will be a guide for proper selection of the antibiotics for the treatment regimen.

This study also confirms that clinical isolates from the hospital environment could possess the EPA mechanism of drug resistance which could be tackled with a suitable EPI. Non-detection of Luk-PV and mecA in the MRSA isolates might be due to the absence of the genes in these isolates or that the genes tested may not be indigenous to our environment suggesting the possibility of other genes yet unknown to be responsible for the resistance detected among these isolates.

\section{CONCLUSION}

This work presents a new development in pharmaceutical microbiology, as it demonstrates that the emergence of efflux pump resistance mechanisms among MDR strains of Staphylococcus and Micrococcus species can be tackled by using a suitable EPI, such as TFMBP, in antibacterial formulations. Further investigation of other suitable EPIs will be of great benefit to the pharmaceutical industry.

\section{DECLARATIONS}

\section{Acknowledgement}

The authors acknowledge the grant support for A.O. Adeluola $(A O A)$, from the University of Lagos, University of Lagos STEP-B office (IOT), and the Association for International Practical Training (AIPT), Columbia, MD, USA. AOA specifically acknowledges the laboratory support from Misher College of Arts and Sciences, University of the Sciences, Philadelphia, USA and the management and staff of the Molecular Biology Department of Nigerian Institute of Medical Research (NIMR), Lagos, Nigeria, and Professor Adeboye Adejare, for facilitating AOA's trip to the University of the Sciences in Philadelphia.

\section{Conflict of Interest}

No conflict of interest associated with this work.

\section{Contribution of Authors}

The authors declare that this work was done by the authors named in this article and all liabilities pertaining to claims relating to the content of this article will be borne by them.

\section{Open Access}

This is an Open Access article that uses a funding model which does not charge readers or their institutions for access and distributed under the terms of the Creative Commons Attribution License (http://creativecommons.org/licenses/by/ 4.0) and the Budapest Open Access Initiative (http://www.budapestopenaccessinitiative.org/rea d), which permit unrestricted use, distribution, and reproduction in any medium, provided the original work is properly credited.

\section{REFERENCES}

1. Fischbach MA, Walsh CT. Antibiotics for emerging pathogens. Science 2009; 325: 1089-1093.

2. Ogunsola FT. Battle of the titans: Can man win the war on microbes? In the Inaugural lecture series 2012. University of Lagos, Nigeria. University of Lagos Press. ISSN 1119-4456.

3. Iroha IR, Amadi ES, Agabus AC, Oji AE. Susceptibility of extended spectrum $\beta$-lactamase-Producing Klebsiella pneumoniae from clinical isolates. Internet $J$ Microbiol 2008; 5(2): 1-4.

Trop J Pharm Res, November 2017; 16(11): 2703 
4. Aibinu IE, Ohaegbulam VC, Adenipekun EA. Ogunsola FT. Extended Spectrum $\beta$-lactamase enzymes in clinical isolates of Enterobacter species from Lagos, Nigeria. $J$ Clin Microbiol 2003; 41(5): 2197-2200.

5. Soge OO, Adeniyi BA, Roberts MC. New antibiotic resistance genes associated with CTX-M plasmids from uropathogenic Nigerian Klebsiella pneumoniae. J Antimicrob Chemother 2006; 58: 1048-1053.

6. Shittu AO, Okon K, Adesida S, Oyedara O. Antibiotic resistance and molecular epidemiology of Staphylococcus aureus in Nigeria. BMC Microbiol 2011; 11: 92.

7. Gruner BM, Han SR, Meyer HG, Wulf U. Characterisation of a catalase-negative methicillin-resistant Staphylococcus aureus strain. J Clin Microbiol 2007; 45(8): 2684-2685.

8. Bohnert JA, Kern WV. Selected Arylpiperazines are capable of reversing multidrug resistance in Escherichia coli overexpressing RND efflux pumps. Antimicrob Agents Chemother 2005; 49(2): 849-852.

9. Cai HI, Archambaul M, Gyles CL, Prescott JF. Molecular genetic methods in the veterinary clinical bacteriology laboratory: current usage and future applications. Anim Health Rev 2003; 4: 73-93.

10. Perreten $V$, Vorlet-Fawer $L$, Slickers $P$, Ehricht $R$, Kuhnert $P$, Frey J. Microarray-based detection of 90 antibiotic resistance genes of Gram-positive bacteria. $J$ Clin Microbiol 2005; 43: 2291-2302.

11. Bauer AW, Kirby WMM, Sherris JC, Turk M. Antibiotic susceptibility testing by standardized single disc method. Am. J. Clin. Pathol. England 1966; 45: 493-496.

12. Livermore DM, Brown DFJ. Detection of $\beta$-lactamasemediated resistance. J Antimicrob Chemother2001; 48(suppl. SI): 59-64.

13. Clinical and Laboratory Standards Institute (CLSI). Performance Standards for Antimicrobial Susceptibility Testing: 20th Informational Supplement, Wayne, PA: CLSI. 2008; CLSI document M100-S20-U, 2010.

14. Pagani L, Dell'Amico E, Migliavacca R, D'Andrea $M$, Giacobone $E$, Amicosante $G$, Romero $E$ and Rossolini $G$ (2003). Multiple CTX-M-type extended-spectrum $\beta$ lactamases in nosocomial isolates of Enterobacteriaceae from a hospital in northern Italy. J. Clin. Microbiol 41(9): 4264-4269.
15. Gallagher and MacDougall. 'Folate antagonists' in Antibiotics simplified from Jones and Bartlett Learning 2nd edition. 2012: 113-116.

16. Zinn CS, Westh H, Vibeke TR, Sarisa Study Group. An international multicenter study of antimicrobial resistance and typing of hospital Staphylococcus aureus isolates from 21 laboratories in 19 countries or states. Microb Drug Resist 2004; 10 (2): 160-168.

17. Hong BK, Hee-Chang J, Hee JN, Yeong SL. In vitro activities of 28 antimicrobial agents against Staphylococcus aureus Isolates from tertiary-care hospitals in Korea: A nationwide survey, 2004. Antimicrob Agents Chemother 2004; 48(4):11241127.

18. Shittu AO, Lin J. Antimicrobial susceptibility patterns of Staphylococcus aureus and characterization of MRSA in South-western Nigeria. Wounds 2006; 18: 77- 84.

19. Nordmann $P$, Cuzon G, Naas T. The real threat of Klebsiella pneumonia carbapenemase-producing bacteria. Lancet Infect Dis 2009; 9:228-236.

20. Stermitz FR, Scriven LN, Tegos G, Lewis K. Two flavonols from Artemisa annua which potentiate the activity of berberine and norfloxacin against a resistant strain of Staphylococcus aureus. Planta Med 2002; 68 (12): 1140-1141.

21. Adeluola AO, Oyedeji KS, Mendie UE, Johnson JR Effect of Efflux Pump Activity Inhibition on Antibiotic Resistance of Bacterial Isolates from Patients Attending Lagos University Teaching Hospital - A Pilot Study. J. Pharm. Sci. Pharm. Pract. (2014). 10 (4):246 - 251.

22. Stavri M, Piddock LJV, Gibbons S. Bacterial efflux pump inhibitor from natural sources. J AntimicrobChemother.2007; 59: 1247-1260.

23. Webber MA, Piddock LJV. The importance of efflux pumps in bacterial antibiotic resistance. J. Antimicrob. Chemother.2003; 51: 9-11.

24. Olayinka BO, Olayinka AT, Obajuluwa AF, Onaolapo JA, Olurinola PF. Absence of meca gene in methicillinresistant Staphylococcus aureus isolates. Afr. J. Infect. Dis. 2009 3(2): 49 - 56

25. Alli OAT, Ogbolu DO, Mustapha JO, Akinbami R, Ajayi AO. The non-association of Panton-Valentine leukocidin and mecA genes in the genome of Staphylococcus aureus from hospitals in South Western Nigeria. Indian Journal of Medical Microbiology.2012. 30(2):159-164. 